\title{
The Effect of Some Soil Physical and Chemical Properties on Soil Aggregate Stability in Different Locations in Sulaimani and Halabja Governorate
}

\author{
Salahaddin Abdulqadir Aziz, Saman Mahmood Karim \\ Department of Soil and Water Sciences, Faculty of Agricultural Sciences, Sulaimani University, Sulaimani, Iraq \\ Email: salahaziz462@yahoo.com,saman.karim@univsul.edu.iq
}

Received 22 January 2016; accepted 22 April 2016; published 25 April 2016

Copyright (C) 2016 by authors and Scientific Research Publishing Inc.

This work is licensed under the Creative Commons Attribution International License (CC BY).

http://creativecommons.org/licenses/by/4.0/

(c) (i) Open Access

\section{Abstract}

Some soil properties were studied in relation soil aggregate along a climatologically region and different crop land use in the Northeast of Sulaimani City/Kurdistan Region of Iraq. Five locations were selected along these regions ranging from semiarid to sub-humid climatologically conditions. The soil physical, chemical properties, aggregate stability and size distribution were analyzed. A mean-weight-diameter (MWD) value was determined on 5 soils, which was the sum of the percentage of soil on each sieve $(6,3,1.5,0.75,0.375$ and $0.125 \mathrm{~mm})$. The results of the measurements could evaluated with linear correlation coefficients for the relationships between aggregate stability (MWD) and soil physical and chemical properties of the different crop land use. The correlation coefficient for the relationship between aggregate stability and organic matter was highly significant $(\mathrm{P}<0.01 \%)$ which is in agreement with the findings of [1]. Generally large aggregates (large 6, 3, $3-1.5 \mathrm{~mm}$ ) were present in highest proportions in the most semiarid of the studied areas. Aggregates $0.75-0.125 \mathrm{~mm}$ were positively correlated to fine, very fine sand and silt fractions and to organic matter. Stability of aggregates showed a positive correlation with clay content and organic matter content, while the carbonate content was strongly correlated with aggregate stability. The land use history affecting soil overlaps the pattern of climatological situations and cultivated crop lands and has to be taken into account. Aggregate size distribution and stability can be used as indicator of soil conservation and productivity.

\section{Keywords}

Aggregate Stability, Organic Matter, Some Physical and Chemical Properties, Soil Consistency Limits 


\section{Introduction}

Soil aggregation is defined as the group of soil particles in which the forces held the particles together [2]. The aggregation is formed by some processes like physical, chemical and biological forces which are mainly responsible for their stabilization [3] [4]. The formation of aggregates are affected by some factors that are involves wetting and drying, and freezing cycles, All these processes are able to bring soil particles close together that the physical and chemical forces between them hold the particles [3]. The soil aggregates stability occurs due to the forcing activating of inorganic and organic materials. The Atterberg limit tests were later adapted by two scientists, [5], to be used as the determination of soil behavior under different conditions. For example, one method of distinguish between clay and silt is by determining the plasticity of the soil. Plasticity refers to the response of a soil to changes in moisture content (Coduto, 128). Silt is slightly plastic, while sand and gravel do not exhibit any plasticity at all and clays can be very plastic. The plasticity index is a measure of the range of moisture contents that encompass the plastic state (Coduto 130) and is the numerical difference between the liquid and plastic limits. Soil aggregate stability is widely used to measure change in soil structure due to different management options [6] [7]. The extent of aggregate disintegration by wetting depends on aggregate stability which is related to organic matter, and clay content [8] [9].

In General, aggregate stability is commonly measured as the percentage of water aggregates with a diameter $>2 \mathrm{~mm}$, a parameter which is relatively easy and faster to measure compared with mean weight diameter (MWD) [10] [11]. Many authors reported, as reviewed by [12], that the soil aggregate stability was controlled by several soil primary characteristics, such as soil texture, clay mineralogy, contents of organic matter, and calcium carbonate. On the other hand, only few studies present about the relationship between the soil aggregate stability and environmental factors such as landscapes [13] and vegetation types [14] examined.

For predicting capability of soil for production in a given sites, the evaluation of the soil aggregate stability in relation to climatology, environmental factors and soil surface coverage would be more suitable parameters which was recognized as soil physical and chemical properties, since these parameters could be determined more readily. Thus, the objective of this study was to predicate the relationships between the soil aggregate stability and the soil surface coverage factors, these relationships will predicate the conditions raising the stability of soil aggregates, which may participate to the increase of efficient soil management to increase the soil aggregate stability.

\section{Material and Methods}

\subsection{Study Area and Soil Samples}

The study area is located in the Northeast of the sulaimani Governorate Iraq. Five sites were selected to carry out this study (Arbat, Bakrajow, Said Sadq, Kani Panka and Anab (Figure 1). These areas were characterized by a strong climatological gradient and cultivated with different crops from South to north, especially with respect to the annual rainfall, with a maximum in the southern site, Bakrajow with more than $750 \mathrm{~mm}$ and a minimum to the Northern site of less than $400 \mathrm{~mm}$ Anab. This climatologically gradient is also reflected in the soil temperature. Distribution and stability of soil aggregates were determined by using separate wet sieving methods [15]. The percentage by weight of aggregates at each fraction and two indexes, (MWD) Mean Weight Diameter [1].

\subsection{Physical and Chemical Analysis of Soil}

For the same soil samples, chemical and physical analysis was performed as follow: particle size distribution was determined after removing the organic matter with $\mathrm{H}_{2} \mathrm{O}_{2} 30 \%$. [16]; $\mathrm{pH}$ was measured in the extract of a soil-solution 1:2.5 in water and salinity was measured in the extract of a soil-water solution 1:5 with a conductivity meter [17]. Total calcium carbonate content was measured according to [18]. Organic matter was measured by wet oxidation $\left(\mathrm{K}_{2} \mathrm{Cr}_{2} \mathrm{O}_{7}\right)$ [19].

\subsection{Soil Consistency Limits}

In this experiment, the Casagrande liquid limit device will be used to determine the liquid limit of the soil sample. The liquid limit is found when 25 drops of the liquid limit device are required to close the groove cut through the sample in a distance of $1 / 2$. The plastic limit is found when the soil sample being rolled breaks at $1 / 8$ in diameter. The moisture content at these limits gives a quantitative measure of these limits. The following eq- 
uations for the mass, liquid limit, plastic limit, moisture content, flow index and plasticity index will be used in the determination of the Atterberg limits of the soil sample, and to further classify the soil type. Increasing soil organic matter is vital in terms of improving the soil physical and mechanical properties related to conditions for root plants and to crop development in arid and semiarid regions. This laboratory study was aimed to assess effects of organic matter on soil consistency limits (liquid limit, LL; plastic limit, PL; plastic index, PI) and soil compatibility parameters in soils with different textures (clay, silty clay, silty clay loam and clay loam). The SOC, consistency limits and plasticity index $(\mathrm{PI}=\mathrm{LL}-\mathrm{PL})$ were measured for the soil taken from the $0-30 \mathrm{~cm}$ layer.

\subsection{Aggregate Stability}

Wet sieving: In this method the Soil is slowly wetted by capillarity for 30 minutes. The wetted immersed in water. The sieves are slowly raised and lowered vertically in the water by mechanical method through a distance of 1.25 inch at a rate of 30 resolutions per minute for 30 minute. The sieves in the nest have an opening from 6.0 $\mathrm{mm}$ to $0.125 \mathrm{~mm}$ [sizes $(6,3,0.75,0.375$, and 0.125$) \mathrm{mm}$ ] Oven dry weight of the fractions of the aggregates retained on each sieve is determined for knowing the proportionate distribution of the aggregates. The fraction of soil is retained on each sieve represents the size range viz. the size of the opening of the sieve on which the fraction of soil is retained and the size of the sieves just above through which is has passed, a wet sieving apparatus (yodder type) [20].

\section{Results and Discussion}

\subsection{Chemical Properties}

\subsubsection{Effect Organic Matter Content on Aggregate Stability (MWD)}

More techniques were used for evaluating soil aggregate stability, like: changes in moisture characteristic, changes in permeability, and wet-sieving [21]. Wet-sieving method was the most suitable technique. The results are expressed as a mean-weight-diameter (MWD) value, which is the sum of the percentage of soil on each sieve multiplied by the mean diameter of adjacent sieves (6.3, 1.5, 0.75, 0.375 and $0.125 \mathrm{~mm}$ ). The results of the measurements carried out on 5 soils studied were presented in Table 2, together with linear correlation coefficients for the relationships between aggregate stability (MWD) and the locations of the soil. The correlation coefficient for the relationship between aggregate stability and organic matter (Table 1, Figure 2) was highly significant $(\mathrm{P}<0.01 \%)$ which is in agreement with the findings of [1].

\subsubsection{Effect of $\left(\mathrm{CaCO}_{3}, \mathrm{Ca}^{++}, \mathrm{Mg}^{++}\right.$and $\left.\mathrm{Na}^{+}\right)$on Aggregate Stability}

Figure 3 and Figure 4, show the results of the study, effectiveness of change variance in climatology sites on chemical properties of the soil and concerned to change in aggregate stability value; in general, significant correlation determination were obtained for the relationships between aggregate stability and $\left(\mathrm{CaCO}_{3}, \mathrm{Ca}^{++}, \mathrm{Mg}^{++}\right.$ and $\mathrm{Na}^{+}$). The variation of these properties will be due, in part, to changes in the organic matter levels. Therefore, it is probable that the significance of these correlations determination is as much as reflection of the organic matter effect as it is of the effect of these properties. The correlation determination between $\mathrm{Na}^{+}$and aggregate stability was not significant (Table 1). Statistical analysis of the data in Bakrajow soil showed that there were higher concentration of calcium salts than magnesium salts, which is less than the predicted flocculation values, which is agree with study of the others [22], that higher concentrations of magnesium salt were required for flocculation.

Effect of cations (Ca, Mg and $\mathrm{Na}$ ) on aggregate stability from statistical analysis data showed in (Table 1) that the increase in (Ca and $\mathrm{Mg}$ ) value caused increasing MWD by range from a low value 1.2 and 0.27 in Anab site to a high value 1.53 and 0.33 in kani-panka site respectively, that is located in a cool climatologically region whereas the value of MWD in this sites were 0.97 to 0.80 , respectively. And the percent of Na in these sites was negative effect on aggregate stability with negative significant difference with aggregate stability.

\subsection{Physical Properties}

\section{Effect Soil Texture on Soil Aggregate Stability}

Figure 5 and Figure 6 showed the sand [23], silt [24] and clay fractions [8], [25] have each been cited as soil 
Table 1. Statistic analysis of the parameters studies of some the chemical properties of the soil at differences locations in sulaimani and halabja governorate.

\begin{tabular}{ccccccc}
\hline \multicolumn{7}{c}{ Treatments } \\
\hline Locations & $\begin{array}{c}\mathrm{CaCO}_{3} \% \\
\%\end{array}$ & $\begin{array}{c}\mathrm{O} \% \mathrm{M} \% \\
\%\end{array}$ & $\mathrm{Ca}^{2+}$ & $\mathrm{Mg}^{2+}$ & $\mathrm{Na}^{+}$ & $\mathrm{MWD}$ \\
& $14 \mathrm{a}$ & $1.22 \mathrm{c}$ & $1.45 \mathrm{ab}$ & $0.35 \mathrm{a}$ & $0.55 \mathrm{a}$ & $0.53 \mathrm{~b}$ \\
Bakrajow & $17 \mathrm{a}$ & $1.35 \mathrm{bc}$ & $1.49 \mathrm{ab}$ & $0.36 \mathrm{a}$ & $0.44 \mathrm{~b}$ & $0.64 \mathrm{~b}$ \\
Said Sadq & $18 \mathrm{a}$ & $1.39 \mathrm{bc}$ & $1.53 \mathrm{ab}$ & $0.33 \mathrm{ab}$ & $0.58 \mathrm{a}$ & $0.80 \mathrm{~b}$ \\
Kani Panka & $20 \mathrm{a}$ & $1.51 \mathrm{~b}$ & $1.40 \mathrm{~b}$ & $0.37 \mathrm{a}$ & $0.40 \mathrm{~b}$ & $0.87 \mathrm{ab}$ \\
Arbat & $15 \mathrm{a}$ & $1.7 \mathrm{a}$ & $1.2 \mathrm{c}$ & $0.27 \mathrm{~b}$ & $0.42 \mathrm{~b}$ & $0.97 \mathrm{a}$ \\
Anab & & & & & \\
\hline
\end{tabular}

Table 2. Regression analysis of liquid limit and SOC in different soil texture class.

\begin{tabular}{cccccccc}
\hline \multirow{2}{*}{ Locations } & Textural classes & $\begin{array}{c}\text { Permeability } \\
(\mathrm{cm} / \mathrm{hr})\end{array}$ & $\begin{array}{c}\text { Shear strength } \\
\text { kpa }\end{array}$ & Liquid limit & Plastic limit & Plasticity index & MWD \\
Bakrajow & Silty & $2.1 \mathrm{c}$ & $6.25 \mathrm{ab}$ & $27.79 \mathrm{e}$ & $17.38 \mathrm{ab}$ & $10.41 \mathrm{~d}$ & $0.53 \mathrm{~b}$ \\
& Clay Loam & & & & & \\
Said Sadq & Clay & $3.2 \mathrm{~b}$ & $7.10 \mathrm{abc}$ & $31.90 \mathrm{~d}$ & $19.14 \mathrm{~d}$ & $12.76 \mathrm{c}$ & $0.64 \mathrm{~b}$ \\
Kani Panka & Clay & $3.5 \mathrm{~b}$ & $7.35 \mathrm{abcd}$ & $35.75 \mathrm{c}$ & $20.15 \mathrm{c}$ & $15.6 \mathrm{~b}$ & $0.80 \mathrm{ab}$ \\
Arbat & Clay & $3.7 \mathrm{ab}$ & $6.75 \mathrm{~cd}$ & $41.98 \mathrm{~b}$ & $21.34 \mathrm{~b}$ & $20.64 \mathrm{a}$ & $0.87 \mathrm{ab}$ \\
Anab & Clay & $4.4 \mathrm{a}$ & $7.75 \mathrm{~d}$ & $44.84 \mathrm{a}$ & $23.42 \mathrm{a}$ & $21.42 \mathrm{a}$ & $0.97 \mathrm{a}$ \\
\hline
\end{tabular}

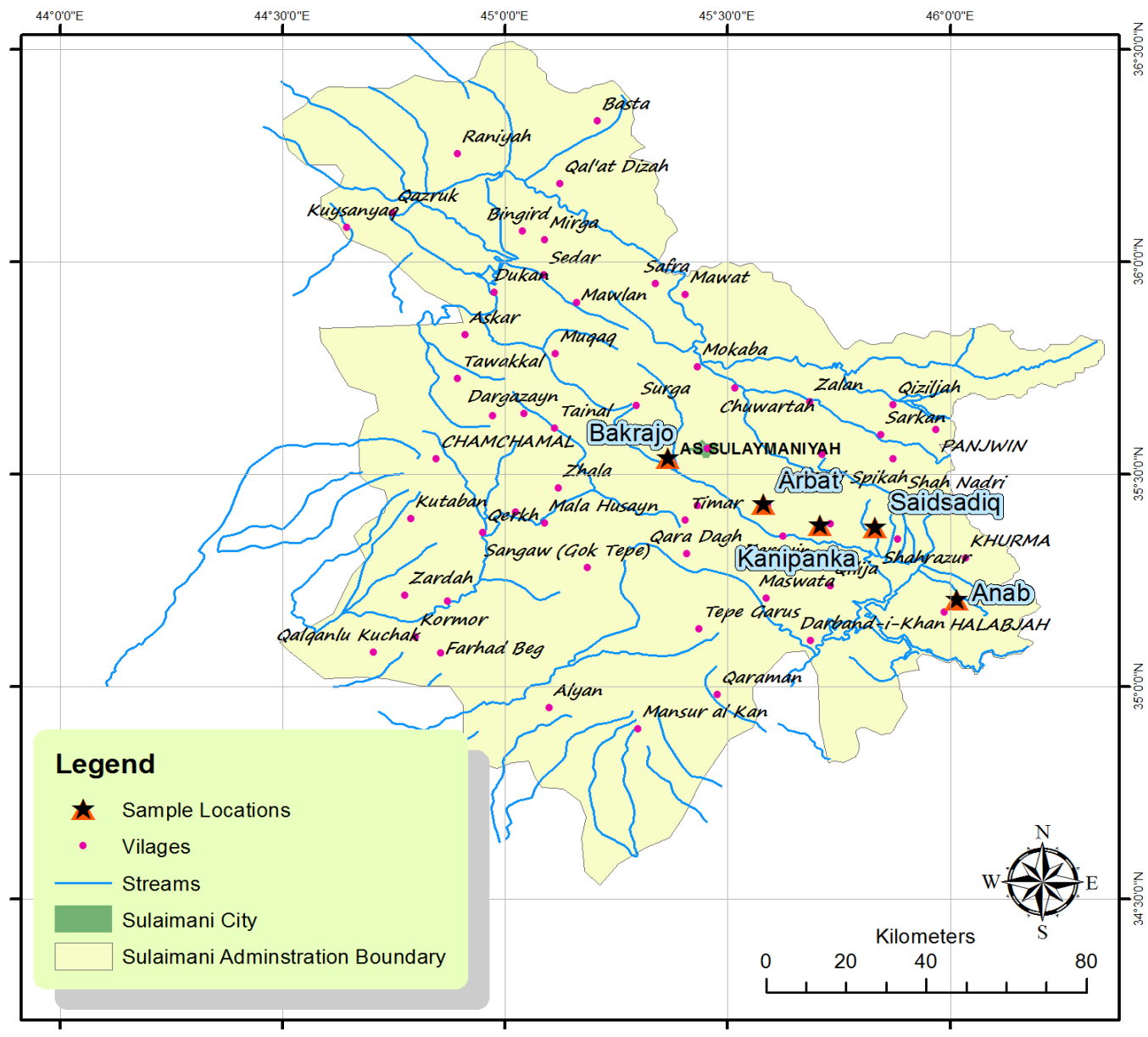

Figure 1. Some selected physical and chemical properties of the study soil at differences locations in Sulaimani and Halabja Governorate. 


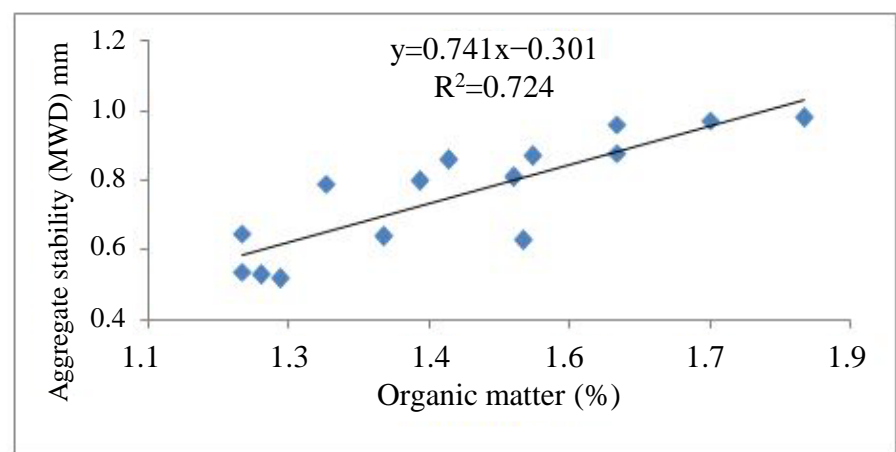

Figure 2. Relationship between aggregate stability (MWD) and organic matter (OM) content for 5 soils.
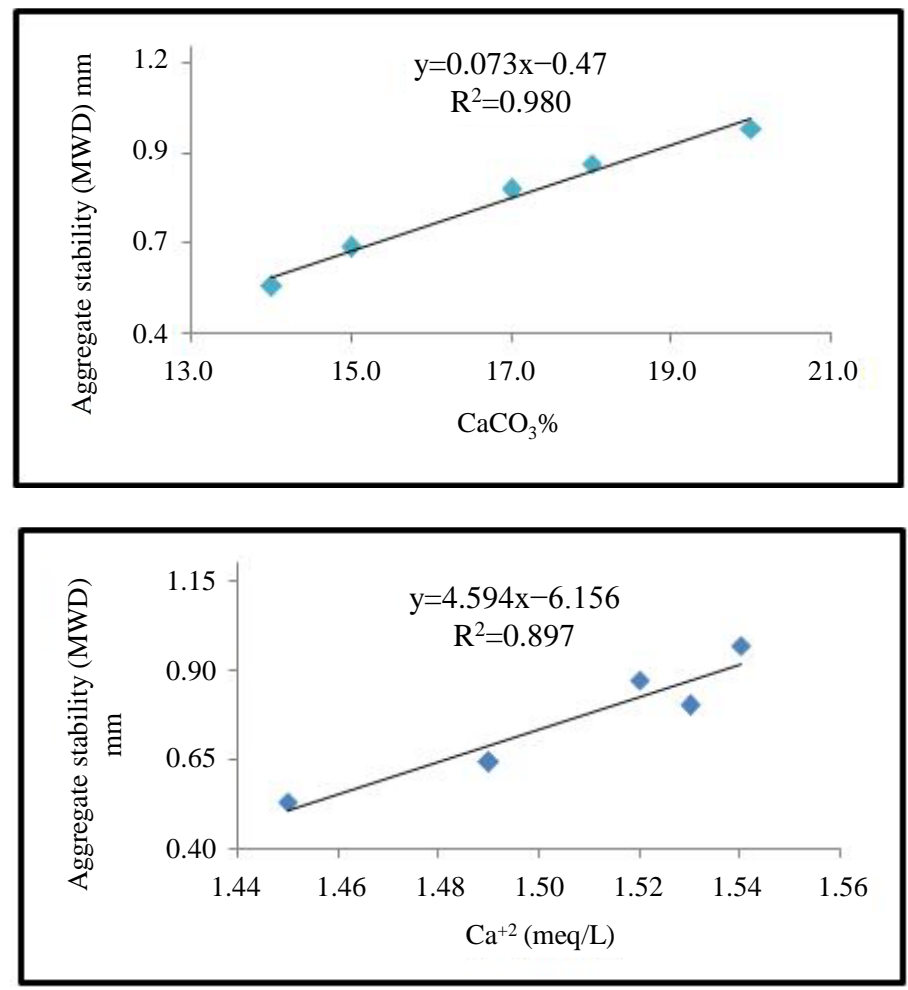

Figure 3. Relationship between aggregate stability and Calcium Carbonate, calcium content.

constituents who have a major influence on the stability of soil aggregates. While this is certainly the case in the studies cited above, the correlation determination calculated between aggregate stability and these three components for the soils examined here are very small ranged in sand (0.84), in silt (0.414) and in clay (0.943) and in no way approach significance (Figure 5 and Figure 6). Although the textural range of the soils used in this study was more restricted than in the studies cited above, there are nonetheless substantial variations in the amounts of sand, silt and clay. Clay percentages range from 38 to 54, silt from 38 to 41 and sand from 8 to 19 . No significant correlation was obtained with sand and silt of the particle size fractions, while significant correlation was obtained with clay content. Tisdall and Oades 1982 [25], proposed an aggregate model depending on the size of the aggregation, that binding agents vary. Aggregates $2000 \mathrm{~mm}$ are held together by a fine network of roots and hyphae in soils with high contents of organic matter. Kemper and Koch (1966) [26] founded that the clay and organic matter act as cementing and binding agents in the soil. Seybold and Herrik (2001) [27] work showed that increase in clay fraction significantly improved water aggregate stability. 

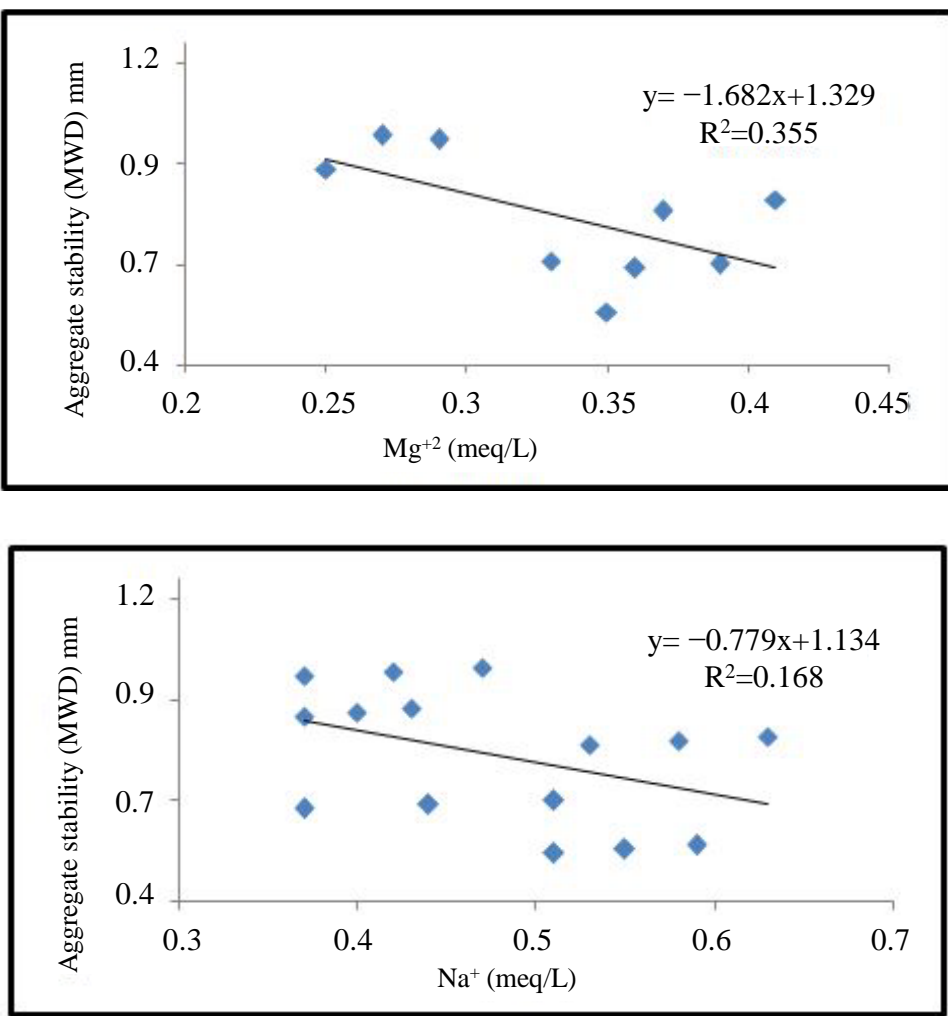

Figure 4. Influence of magnesium and sodium on aggregate stability.
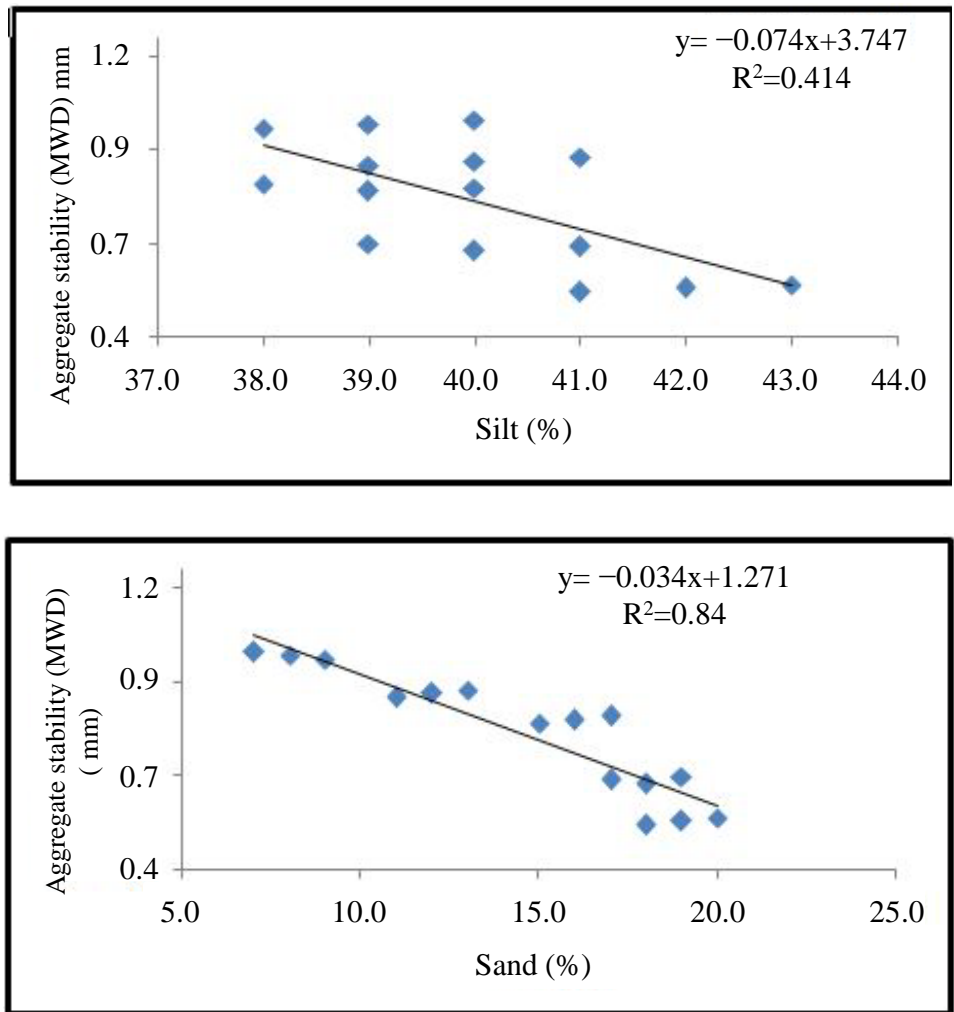

Figure 5. Corelation determination between Aggregate stability (MWD $\mathrm{mm})$ and Sand and Silt \%. 


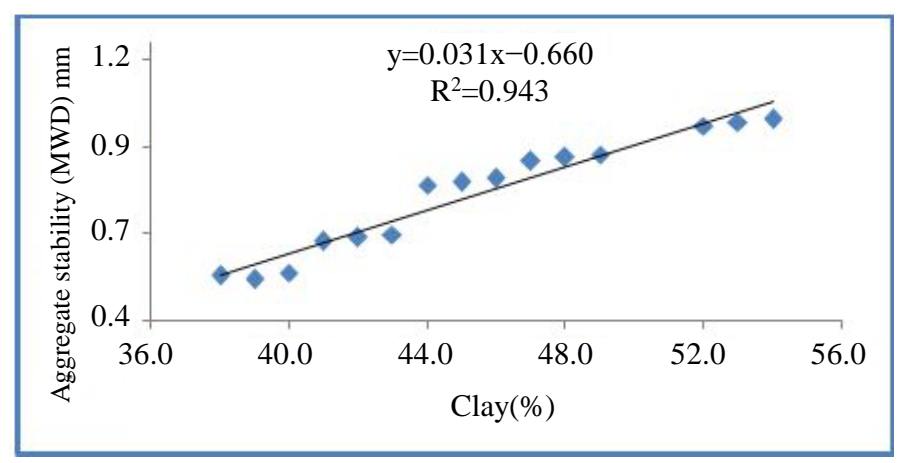

Figure 6. Correlation determination between aggregate stability (MWD mm) and Clay \%.

The composition of any soil is an important factor which influences many soil properties, such as shear strength, liquid limit (LL), plastic limit (PL) permeability etc. Table 2 shows the results of this study with changes of the properties that affect on aggregate stability (MWD) from the range 6.25 to 7.75 , 27.79 to 44.84, 17.38 to 23.42 and 2.1 to $4.4 \mathrm{~cm} / \mathrm{h}$ as sequenced. This paper examines the effects of treatments inducing the organic matter content on the Atterberg limits of four different soils texture class. The results of regression value analysis for shear strength, liquid limit, plastic limit, and permeability in different soil texture class (Table 2 and Figures 1-4) indicated that SOC in clay soil texture class can justify 98.9 percent of the liquid limit variation. So this traits the most important component of liquid limit.

\section{References}

[1] Chaney, K. and Swift, R.S. (1984) The Influence of Organic Matter on Aggregate Stability in Some British Soils. European Journal of Soil Science, 35, 223-230. http://dx.doi.org/10.1111/j.1365-2389.1984.tb00278.x

[2] Martin, J.P., Martin, W.P., Page, J.B., Raney, W.A. and De Ment, J.D. (1955) Soil Aggregation. Advances in Agronomy, 7, 1-37. http://dx.doi.org/10.1016/S0065-2113(08)60333-8

[3] Allison, F.E. (1968) Soil Aggregation-Some Facts and Fallacies as Seen by a Microbiologist. Soil Science, 106, 136-143. http://dx.doi.org/10.1097/00010694-196808000-00010

[4] Lynch, J.M. and Bragg, E. (1985) Microorganisms and Soil Aggregate Stability. Advances in Soil Science, 2, $133-171$. http://dx.doi.org/10.1007/978-1-4612-5088-3_3

[5] Terzaghi, K. and Casagrande, A. (1930s) Adopted Atterberg's Tests to Civil Engineering Applications, the Liquid Limit, the Plastic Limit and the Shrinkage Limits Are Now Known as the Atterberg Limits, and Are Defined hrough ASTM's D-427 and D-4318.

[6] Hussein, J., Adey, M.A. and Elwell, H.A. (1992) Irrigation and Dry Land Cultivation Effects on the Surface Properties and Erodibility of a Zimbabwe Vertisol. Soil Use and Management, 8, 97-103. http://dx.doi.org/10.1111/j.1475-2743.1992.tb00901.x

[7] Salako, F.K., Babalola, O., Hauser, S. and Kang, B.T. (1999) Soil Micro Aggregate Stability under Different Fallow Management Systems and Cropping Intensities in South Western Nigeria. Geoderma, 91, 103-123. http://dx.doi.org/10.1016/S0016-7061(99)00006-3

[8] Kemperw, D. and Koch, E.J. (1966) Aggregate Stability of Soils from Western United States and Canada. U. S D.A. Technical Bulletin No. 1355.

[9] Kay, B.D. and Angers, D.A. (1999) Structure. In: Sumner, M.E., Ed., Handbook of Soil Science, A229-A276.

[10] Elwell, H.A. (1986) Modelling Sheet Erosion and Run-Off from a Fersiallittic Clay by Combined Small-Scal Physical Simulation Techniques and Field Studies. D.Phil. Thesis, University of Zimbabwe, 233.

[11] Elwell, H.A. (1987) Modeling Sheet Erosion and Runoff from a Fersiallitic Clay by Combined Small-Scale Physical Simulation Techniques and Field Studies. PhD Thesis, University of Zimbabwe, Harare, 233.

[12] Le Bissonnais, Y. (1996) Soil Characteristics and Aggregate Stability. In: Agassi, M., Ed., Soil Erosion, Conservation, and Rehabilitation, Marcel Dekker, Inc., New York, 41-60.

[13] Pierson, F.B. and Mulla, D.J. (1990) Aggregate Stability in the Palouse Region of Washington: Effect of Landscape Position. Soil Science Society of America Journal, 54, 1407-1412.

http://dx.doi.org/10.2136/sssaj1990.03615995005400050033x 
[14] Cerda, A. (1998) Soil Aggregate Stability under Different Mediterranean Vegetation Types. Catena, 32, 73-86. http://dx.doi.org/10.1016/S0341-8162(98)00041-1

[15] Dane, J.H. and Topp, G.C. (Eds.) (2002) Methods of Soil Analysis, Part 4, Physical Methods. Soil Science Society of America Book Series, No. 5, Soil Science Society of America, Madison, 1692 p.

[16] Ministerio de Agricultura (1986) Métodos oficiales de análisis de suelos, III. Ministerio de Agricultura, Madrid, 166 p.

[17] Richards, L.A. (1954) Diagnosis and Improvement of Saline and Alkali Soils. Agriculture Handbook, Vol. 60, USDA, Washington DC, $160 \mathrm{p}$.

[18] Jackson, M.L. (1958) Soil Chemical Analysis. Prentice Hall, Englewood Cliff, 480 p.

[19] Walkley, A. and Black, I.A. (1934) An Examination of the Degtjaredd Method for Determining Soil Organic Matter and Proposed Modification of the Chromic Titration Method. Soil Science, 37, 29-38. http://dx.doi.org/10.1097/00010694-193401000-00003

[20] Yoder, R.E. (1936) A Direct Method of Aggregate Analysis of Soils and a Study of the Physical Nature of Soil Erosion Losses. American Society of Agronomy Journal, 28, 337-351. http://dx.doi.org/10.2134/agronj1936.00021962002800050001x

[21] Chaney, K. (1978) The Influence of Soil Organic Matter on Soil Structure. PhD Thesis, Edinburgh University, Edinburgh.

[22] Rengasamy, P., Greene, R.S.B. and Ford, G.W. (1986) Influence of Magnesium on Aggregate Stability in Sodic Red-Brown Earths. Australian Journal of Soil Research, 24, 229-237. http://dx.doi.org/10.1071/SR9860229

[23] Willamrs, J.B. (1970) Relationships between the Composition of Soils and Physical Measurements Soil Aggregation as Influenced by Microbial Made on Them. Rothamsted Experimental Station Report, Part 2, 5-35.

[24] Thomassona, H. (1978) Towards an Objective Classification of Soil Structure. Journal of Soil Science, 29, 38-46. http://dx.doi.org/10.1111/j.1365-2389.1978.tb02029.x

[25] Tisdall, J.M. and Oades, J.M. (1982) Organic Matter and Water-Stable Aggregates in Soils. Journal of Soil Science, 33, 141-163. http://dx.doi.org/10.1111/j.1365-2389.1982.tb01755.x

[26] Kemper, W.D. and Koch, E.J. (1966) Aggregate Stability of Soils from Western USA and Canada. USDA Technical Bulletin No. 1355, US Government Printing Office, Washington DC.

[27] Seybold, C.A. and Herrick, J.E. (2001) Aggregate Stability Kit for Soil Quality Assessments. Catena, 44, 37-45. http://dx.doi.org/10.1016/S0341-8162(00)00175-2 